\title{
Olli Löytty
}

\section{Sanatiedeteosten tutkimisesta}

Erään tietokirjan mukaan Suomeen pitäisi liittää ne alueet Luoteis-Venäjältä, joissa tavataan samaa prekambrista kallioperää kuin Suomen valtion alueella. Kirjan kirjoittaneen kahden arvostetun tutkijan mukaan valtion muoto voidaan siis määritellä geologian avulla. Tämä on yksi tieteellinen totuus kysymyksestä, joka hiertää yhä monien suomalaisten mieltä: koko Itä-Karjala aina Kuolaa myöten kuuluu Suomeen, koska siellä tavattava kallioperä yhdistää alueet toisiinsa.

Tietokirjallisuus on laaja käsite, jonka piiriin luetaan yleisesti kaikki ei-kaunokirjallisuus (non-fiction), esimerkiksi hakuteokset, käsikirjat, elämäkerrat, pamfletit, oppaat ja oppikirjat. Esteettistä sisältöä käsitteellä ei ole, ellei sitten "asiatyyliä" katsota tietokirjallisuudelle tyypilliseksi esitystavaksi. Sanasta voi oikeastaan päätellä vain sen, että kyse on kirjallisuudesta, jossa tuotetaan ja välitetään tietoa.

Kirjoista saatava tieto on yhä vallitsevan ajattelutavan mukaan painavampaa kuin lehdistä tai internetistä luettu. Moniin muihin puheen ja tekstin lajeihin verrattuna tietokirjallisuudessa on kyse punnitusta, harkitusta, koetellusta, huolitellusta, perustellusta, argumentoidusta ja dokumentoidusta tiedosta, joka on usein läpäissyt paitsi kustantajan toimitusprosessin myös monissa tapauksissa tiedeyhteisön sisäisen laadunvalvonnan. Tietokirjallisuudella katsotaan olevan tärkeä rooli tieteellisen tiedon popularisoimisessa ja levittämisessä, ja sen lukemista pidetään luotettavana keinona hankkia tietoa. Tietokirjat osallistuvat myös yhteiskunnalliseen keskusteluun tekemällä uusia avauksia ja tarjoamalla perusteltuja näkökulmia käsiteltäviin aiheisiin.

Vaikka tietokirjallisuudeksi yleensä nimetään ennen muuta yleistajuiset kirjat, tietoja tiedekirjallisuuden erottaminen toisistaan on sikäli hankalaa, että esimerkiksi monet humanistiset tutkimukset voidaan lukea yhtä lailla kumpaankin kategoriaan (Hiidenmaa 2006, 225). Käyttötarkoituskaan ei tarjoa yksiselitteisiä kriteerejä tietokirjallisuuden määrittelyyn, jos kohta käyttökirjallisuuden käsite voi tarjota kiintoisan näkökulman tietokirjallisuuden erityislaadun tarkastelemiseksi (Varpio 1982). Esseen kaltaiset kauno- ja tietokirjallisuuden rajamailla sijaitsevat tekstilajit auttavat puolestaan kyseenalaistamaan vallitsevia luokitteluja. Essee- ja tutkimuskirjoittamisen eroja tarkastelemalla voi taas osoittaa niin tyyleihin kuin argumentaatioonkin liittyviä konventioita (Riikonen 1990, 19). 
Mutta puhutaanpa sitten tieto- tai tiedekirjallisuudesta, herää kysymys: Eikö näinkin hegemoninen tiedon tuotannon muoto kaipaisi kriittistä ja analyyttistä katsetta? On oikeastaan ihme, ettei tieto- ja tiedekirjallisuus kuulu mitenkään itsestään selvästi minkään vakiintuneen tutkimusalan kohteisiin.

Miten tieto- ja tiedekirjallisuutta voisi tutkia? Kirjallisuudentutkimuksen kontekstissa asiaa tarkasteltaessa olisi ratkaistava se, miten pitäisi suhtautua faktan ja fiktion erotteluun. (Tai sitten on yksinkertaisesti tunnustettava, että kysymys on problematisoitava joka kerta uudelleen; mallia tarjoaa esimerkiksi Roland Barthes esseessään Historian diskurssi, suom. 1993.) Toisaalta olisi pohdittava sitäkin, voiko analyysissa ylipäätään erottaa toisistaan sisällön ("tieto") ja muodon ("kirjallisuus").

Millainen olisi tietokirjallisuudentutkimuksen suhde tieteentutkimukseen? Vuonna 2004 julkaistiin Mika Kiikerin ja Petri Ylikosken lupaavalla otsikolla varustettu kirja Tiede tutkimuskohteena: filosofinen johdatus tieteentutkimukseen. Siinä on kuitenkin kyse lähinnä tutkimuksen tekemisen eikä niinkään tieteen tekstuaalisuuden ja retoriikan tutkimuksesta. Kirjan lähdeluettelosta ei löydy esimerkiksi Heikki Luostarisen ja Esa Väliverrosen teosta Tekstinsyöjät: yhteiskuntatieteellisen kirjallisuuden lukutaidosta (1991), jossa painottuvat nimenomaan retoriikantutkimuksen alaan kuuluvat kysymykset. Siinä missä ensin mainitun teoksen alaotsikossa puhutaan filosofiasta - mitä se sitten milloinkin tarkoittaa -, jälkimmäisen teoksen avainsana on lukutaito.

Millaista taitoa vaatisi tiede- tai tutkimustekstien lukeminen kirjallisuutena? Vaikka tiede ja kirjallisuus nähdäänkin nykyään jopa toistensa vastakohdiksi, ero ei ole koskaan ollut selvä. Modernin ihmistieteen kehittymistä voikin tarkastella erottautumisena siitä, mitä pidetään kirjallisuutena. Tässä suhteessa tieteellistä kirjallisuutta voi lukea ja tutkia omana kirjallisuudenlajinaan, jolle on ominaista muun muassa juuri se, että se kieltää olevansa kirjallisuutta. Luostarinen ja Väliverronen kirjoittavat Tekstinsyöjissä, että "se, mikä selvimmin erottaa tieteen ja kirjallisuuden, on niiden suhde kieleen". (Luostarinen \& Väliverronen 1991, 59, 61.)

Mikä tieteen kielikäsityksessä sitten on erityistä? Siitä huolimatta, että ihmistieteellinen tutkimus on käytännössä lähinnä lukemista ja kirjoittamista, kieltä pidetään tutkimuksenteossa usein varsin ongelmattomana kommunikaation välineenä. Esitellessään tutkimukseen kohdistuvaa retoriikantutkimusta Marja Keränen kirjoittaa, että tieteellisessä kirjoittamisessa ei ole kyse "pelkästä kirjaamisesta, havaintojen raportoinnista läpinäkyvän kielen avulla, vaan aina tulosten tulkinnasta ja 'kääntämisestä’ toiselle kielelle". Kirjoittaessaan tutkijat noudattavat oman tutkimusalansa tai -suuntauksensa konventioita ja genreen sisältyviä normeja. Retoriikantutkimuksen kannalta ongelma piilee Keräsen mukaan tieteellisen tekstin hämärtyneessä ja esineistyneessä luonteessa. Koska tieteen kieli peittää retorisen rakenteensa ja esiintyy 
neutraalina ja läpinäkyvänä, se estää näkemästä tieteellisen kielen suostuttelevan ulottuvuuden. Myös tieteellinen auktoriteetti tuotetaan retorisin keinoin. (Keränen 1996, 112-113.)

Yleisluontoisesti määritellen tutkimus on sitä, että tutkija esittää kysymyksiä tutkimuskohteelleen. Kirjallisuutta - siis lähinnä kaunokirjallisuutta - on Suomessa usein tutkittu osana kansallista itsemäärittelyä. Mitä tietokirjallisuudelta pitäisi kysyä, jos haluaa tietää jotain suomalaisuudesta tai Suomesta kansakuntana?

Yleisteoksissa, oppikirjoissa ja tietosanakirjoissa Suomi on lähinnä maantiedettä, geologiaa, demografiaa, taloutta ja historiaa. Kansakunnan strategiset mitat löytyvät toisinaan niin sanotuista tietolaatikoista. Historia voi puolestaan olla politiikan ja julkisuuden tapahtumia, sosiaalisia suhteita, kulttuuria tai kaupankäyntiä. Yleisesitykseen sekoitetaan yleensä näitä kaikkia. Tietokirjallisuuden Suomi voi siis koostua yhtä lailla "kovista faktoista" (mitoista ja määristä) kuin kertomuksistakin. Tästä syystä tietokirjallisuuden tutkiminen ei voi olla ainoastaan kirjoitetun tekstin tutkimista, vaan huomiota pitää kiinnittää myös kuvien, kuvatekstien, kaavioiden, luetteloiden ja muiden vastaavien havainnollistusten sekä tekstien suhteisiin. (Oppikirjojen tutkimisesta, ks. Hiidenmaa 2003, 216-219.)

Kuvitellaanpa tietokirjaan sisältyvä karttalehti, johon on piirretty nuolia kuvaamaan suomensukuisten kielten leviämistä lähialueilla. Kartalla kieli itse on toimija, se lähtee liikkeelle jostakin Uralin takaa, jakautuu osiksi, joista yksi löytää tiensä Suomen niemelle. Siitä huolimatta, että karttaesitys on aina pysäytyskuva, tarinassa suomen kielen vaiheista kieli ja paikka näyttävät löytävän toisensa ja elävän onnellisina yhdessä maailman tappiin saakka. Vaikka tekstissä asiaa ei ilmaistaisikaan näin yksiselitteisesti, visuaalinen esitys tekee suomen kielen vaiheista eräänlaisen boy-meets-girl-tarinan onnellisine loppuineen.

Pinta-alan, väestömäärän ja valtiomuodon kaltaisten tietojen lukemisen ja tulkitsemisen ei yleensä katsota vaativan analyyttisiä erityistaitoja. Faktat eivät kuitenkaan putoa tietokirjoihin niin sanotusti taivaalta, vaan ne ovat aina valintoja ja kertovat myös siitä, mitä on jätetty valitsematta. Valintaprosessi kertoo arvoista ja arvostuksista. Näitä niin sanottuja faktoja voidaan käyttää myös tietoisen tarkoitushakuisesti.

Alussa mainitsemani raflaava väite Suomen "luonnollisista" rajoista on peräisin geologi Väinö Auerin ja historioitsija Eino Jutikkalan teoksesta Finnlands Lebensraum (1941). Tuossa Suomen valtiovallan sota-aikana teettämässä ja Saksan markkinoille suunnatussa tietokirjassa perustellaan Suomen rajojen laajentamista itään päin tietyn Suomea ja Itä-Karjalaa yhdistävän kallioperätyypin rajojen mukaisesti. Minulla ei ole mitään syytä epäillä, etteivätkö kirjassa esitetyt geologiset faktat olisi aivan oikein, mutta niiden käyttö politiikan välineinä on vähintäänkin epäilyttävää. 
Paljastavaa tällaisissa esityksissä onkin se, kuinka politiikka yritetään palauttaa empiirisesti mitattavaan todellisuuteen. Humanistina minua kiinnostaa ennen kaikkea se, miten niinkin "faktuaalinen" tieteenala kuin geologia taipuu vaivatta nationalismin käyttöön; onhan kansakuntien rajoja kuvattu nimenomaan kuvitelluiksi, fiktion tuotteiksi (Anderson 2007).

Tietokirjallisuudentutkimuksen kannalta Auerin ja Jutikkalan kirjan "asiasisällön" sijaan tärkeäksi kysymykseksi nouseekin se, miten lukijaa pyritään vakuuttamaan Suur-Suomen rajojen geologisesta perustasta. Olennaista ei siis olisi kysyä sitä, ovatko kirjassa esitetyt faktat oikein tai väärin, vaan sitä, miten niitä käytetään ja miten niillä pyritään vaikuttamaan lukijoihin.

Lukutavan erityisyys käy ilmi, kun sitä vertaa tieteelliseen vertaisarviointiin. Teoksen tieteellistä pätevyyttä arvioitaessa oltaisiin kiinnostuneita siitä, pitävätkö Finnlands Lebensraum -teoksessa esitetyt tiedot paikkansa, kun taas tietokirjallisuuden tutkimus voisi kiinnittää huomion esimerkiksi siihen, millainen utopia Suomesta teoksessa rakentuu. Geologisten faktojen "paikkansapitävyyden" sijaan tietokirjallisuuden tutkimus voisi siis olla kiinnostunut teoksessa tuotettavasta konstruktiosta nimeltä Suomi. Toinen nimi tälle konstruktiolle on fiktio eli kuvitelma. Palaamme jälleen kirjallisuudentutkimukseen.

Kirjallisuudentutkimuksessa vaikuttaa yhä paradigma, jossa tutkimuskohteena ovat tekstit sinällään, jolloin niin tekijät kuin lukijatkin - muusta "tekstinulkoisesta” maailmasta puhumattakaan - katsotaan tulkinnan kannalta toisarvoisiksi. Vaikka Finnlands Lebensraum -teoksen tarkastelu itsenäisenä "sanatiedeteoksena" saattaisi tuottaa vähintäänkin mielenkiintoisia tuloksia, jäisi tulkinnasta puuttumaan jotain olennaista. Tästä syystä analyysilta onkin syytä penätä myös kontekstuaalisuutta eli sitä, että tutkimuskysymyksissä ja tulkinnoissa näkyy myös tekstinulkoinen maailma, tässä tapauksessa ainakin ilmestymisajankohdan poliittiset pyrinnöt.

Olen tässä kirjoituksessa tarjonnut tietokirjallisuudentutkimukselle kysymyksenasettelua, joka johtaa pohtimaan tekstien ideologioita. Se on kuitenkin vain yksi lähestymistapa monien mahdollisuuksien joukossa. Koska tietokirjallisuutta ei tutkita millään tutkimusalalla nimenomaan tietokirjallisuutena, kaivataan ensisijaisesti niin sanottua perustutkimusta. Yleiskuvan tietokirjallisuuden kentän moninaisuudesta saa esimerkiksi Risto Nikun tuoreesta teoksesta Suomalaisia tietokirjailijoita (2008), jossa esitellään 50 aktiivista tekijää. Mutta ennen kuin on olemassa jonkinlainen yleisluontoinen selvitys suomalaisen tietokirjallisuuden historiasta, spesifimpi kysymyksenasettelu seisoo ainakin osittain tyhjän päällä. Miten tietokirjallisuuden lajit ovat kehittyneet? Paljonko Suomessa on eri aikoina julkaistu tietokirjallisuutta? Mielessäni väikkyy unelma tietokirjallisuudentutkijoista, jotka eivät kaihtaisi sen enempää formalistisia, semanttisia kuin pragmaattisiakaan kysymyksenasetteluita. 


\section{Kirjallisuus}

ANDERSON, BENEDICT 2007: Kuvitellut yhteisöt. Nationalismin alkuperän ja leviämisen tarkastelua. Suom. Joel Kuortti. Tampere: Vastapaino.

AUER, VÄINÖ \& JUTIKKALA, EINO I94I: Finnlands Lebensraum: das geographische und geschichtliche Finnland / als Sachkundiger in philologischen und ethnographischen Fragen: Kustaa Vilkuna. Berlin: Alfred Metzner Verlag.

Barthes, roland i993: Historian diskurssi. (Alk. 1967.) Teoksessa Roland Barthes: Tekijän kuolema, tekstin syntymä. Toim. Lea Rojola. Tampere: Vastapaino.

HIIDENMAA, PIRJO 2002: Suomen kieli - who cares? Helsinki: Tammi.

HiIdenmaA, PIRJo 2006: Miksei tietokirjallisuutta tutkita. Teoksessa Juha Herkman, Pirjo Hiidenmaa, Sanna Kivimäki \& Olli Löytty (toim.) Tutkimusten maailma. Suomalaista kulttuurintutkimusta kartoittamassa. Nykykulttuurin tutkimuskeskuksen julkaisuja 87. Jyväskylä: Jyväskylän yliopisto.

KerÄNen, MARJA 1996: Tieteet retoriikkana. Teoksessa Kari Palonen \& Hilkka Summa (toim.) Pelkkää retoriikkaa. Tutkimuksen ja politiikan retoriikat. Tampere: Vastapaino.

KIIKERI, MIKA \& YLIKOSKI, PETRI 2004: Tiede tutkimuskohteena: Filosofinen johdatus tieteentutkimukseen. Helsinki: Gaudeamus.

LUOSTARINEN, HeIKKI \& VÄLIVERRONEN, ESA I99I: Tekstinsyöjät. Yhteiskuntatieteellisen kirjallisuuden lukutaidosta. Tampere: Vastapaino.

NIKU, RISTO 2008: Suomalaisia tietokirjailijoita. Helsinki: BTJ Kustannus.

RIIKONEN, H.K. I990: Mikä on essee? Helsinki: SKS.

VARPIO, YRJÖ I982: Käyttökirjallisuus. Kaunokirjallisuuden rajankäyntiä ja rajatapausten estetiikkaa. Helsinki: Kirjastopalvelu. 